\title{
Corals and calcified hydroids of the Manuel Luiz Marine State Park (State of Maranhão, Northeast Brazil)
}

\author{
Fernanda Duarte Amaral ${ }^{1,4}$, Marco Mariante Hudson', \\ Andrea Quirino Steiner ${ }^{3}$ \& Carla Alecrim Colaço Ramos ${ }^{1}$ \\ Biota Neotropica $v 7$ (n3) - http://www.biotaneotropica.org.br/v7n3/en/abstract?article+bn00907032007 \\ Data Received 29/03/07 \\ Revised 24/07/07 \\ Accepted 01/09/07 \\ ${ }^{1}$ Área de Zoologia, Departamento de Biologia, Universidade Federal Rural de Pernambuco, \\ Rua Dom Manoel de Medeiros, s/n, Dois Irmãos, CEP 52171-900 \\ Recife, Pernambuco, Brasil, http://www.ufrpe.br \\ ${ }^{2} I B A M A$ - DF, SAS Qd. 05, Lote 05, Bl. "H”, CEP 70.070-000, Brasília, DF \\ ${ }^{3}$ Associação Pernambucana de Defesa da Natureza - ASPAN \\ ${ }^{4}$ Corresponding author: Fernanda Duarte Amaral, e-mail: fdamaral@db.ufrpe.br
}

\begin{abstract}
Amaral, F.D., Hudson, M.M., Steiner, A.Q. \& Ramos, C.A.C. Corals and calcified hydroids of the Manuel Luiz Marine State Park (State of Maranhão, Northeast Brazil). Biota Neotrop. Sep/Dez 2007 vol. 7, no. 3 http://www.biotaneotropica.org.br/v7n3/en/abstract?article+bn00907032007. ISSN 1676-0603.

This study aimed to collect information on the diversity of corals and calcified hydroids of the Manuel Luiz Marine State Park (state of Maranhão, Northeast Brazil) to aid in the development of a management plan for the park. A total of 21 cnidarian species were identified, of which 16 were corals and calcified hydroids. The bathymetric and geographic distribution of each of these species was extended. This area has a rich coral fauna in relation to other parts of Brazil and is comparable in diversity to the Abrolhos Islands (Bahia State) - an unexpected result considering the region's proximity to the Amazon River Basin. Most of the specimens of corals and calcified hydroids observed were bleached.
\end{abstract}

Keywords: corals, calcified hydroids, Manuel Luiz Marine State Park, Brazil cnidarian diversity.

\section{Resumo}

Amaral, F.D., Hudson, M.M., Steiner, A.Q. \& Ramos, C.A.C. Corais e hidróides calcários do Parque Estadual Marinho do Manuel Luiz (Estado do Maranhão, Nordeste do Brasil). Biota Neotrop. Sep/Dez 2007 vol. 7, no. 3 http://www.biotaneotropica.org.br/v7n3/en/abstract?article+bn00907032007. ISSN 1676-0603.

O objetivo deste estudo foi obter informação sobre a diversidade dos corais e dos hidróides calcários do Parque Estadual Marinho do Parcel do Manuel Luiz (Estado do Maranhão, Nordeste do Brasil) para dar subsídios no desenvolvimento do plano de manejo do parque. Um total de 21 espécies de cnidários foi identificado, dos quais 16 eram corais e hidróides calcários. A distribuição batimétrica e geográfica de cada uma das espécies foram ampliadas. Esta área tem uma fauna coralínea rica com relação a outras partes do Brasil e é comparável em diversidade ao Arquipélago de Abrolhos (Estado de Bahia), um resultado inesperado considerando a proximidade da região à Bacia do Rio Amazonas. A maioria dos espécimes dos corais e dos hidróides calcários observados estava branqueada.

Palavras-chave: corais, hidróides calcários, Parque Estadual Marinho do Parcel do Manuel Luiz, diversidade dos cnidários do Brasil. 


\section{Introduction}

Modern studies on the diversity of stony corals in Brazil began with the research of Laborel $(1969,1970)$; subsequent work includes that of Maida and Ferreira (1997), Castro and Pires (2001), Leão et al. (2003), Couto et al. (2003) and Prates (2006). Amaral et al. (2002a) provided in-depth information on Brazilian calcified hydroids. Studies on specific Brazilian areas where the diversity of corals were studied are: Abrolhos (Bahia State) by Leão and Kikuchi (2005), Pires et al. (1992) on the cnidarians of Fernando de Noronha Archipelago (Pernambuco State), Maÿal and Bezerra (1994/1995) and Echeverría et al. (1997) on Rocas Atoll (Rio Grande do Norte State), Migotto et al. (1999) on the cnidarians of São Paulo State and Amaral et al. (2002b, 2006b) on the cnidarians of São Pedro e São Paulo Archipelago.

The Manuel Luiz Marine State Park (Figure 1) was the first Brazilian Marine State Park and was established in June 1991 in order to preserve one of the major South American coral banks. It is located in the state of Maranhão $\left(00^{\circ} 46^{\prime} \mathrm{S}\right.$ and $\left.44^{\circ} 15^{\prime} \mathrm{W}\right), 179 \mathrm{~km}$ off the northern edge of São Luís Island (Coura 1994), and is influenced by the South Equatorial Current (SEC), North Brazil Current (NBC), and Equatorial Undercurrent (EUC) (Travassos et al. 1999). Visual observations have revealed an area of numerous "coral pillars" up to $20 \mathrm{~m}$ high that emerge during low tide and make navigation especially difficult. According to Coura (1994), 13 shipwrecks have already been found among the estimated 200 that may lie in the region (Maida and

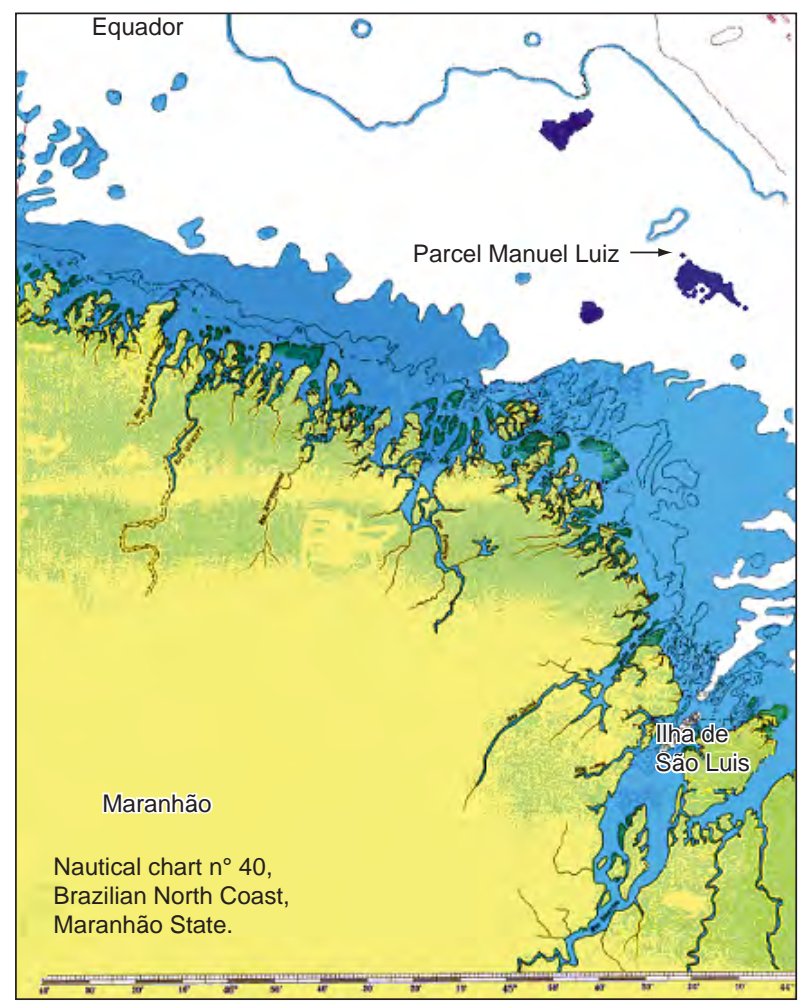

Figure 1. Map of the coast of Maranhão State, showing the location of the Manuel Luiz Marine State Park (based on nautical chart $n^{\circ} 40$ of Brazilian Navy, Diretoria de Hidrografia e Navegação - DHN).

Figura 1. Mapa da costa do Estado do Maranhão, indicando a localização do Parque Estadual Marinho do Manuel Luiz (baseado na carta náutica $n^{\circ} 40$ da Marinha Brasileira, Diretoria de Hidrografia e Navegação - DHN).
Ferreira 1997). Due to the bathymetry and strong currents, studies there are scarce and there is still little geological and physical-chemical data for those coral banks.

In previous studies of the Maranhão region's Cnidaria, Laborel (1970) and Belém et al. (1986) found only Meandrina braziliensis, whereas Coura (1994), in a specific study of the coral banks, listed 4 genera of corals: Agaricia, Meandrina, Mussismilia and Siderastrea, Amaral et al. (1998), Hudson (2000) and recently Amaral et al. (2006a) registered the widespread bleaching on corals and calcified hydroids in the study area. The aim of this study was to gain information on the diversity and skeletal morphometry of corals and calcified hydroids of the Manuel Luiz Marine State Park (Maranhão State) to assist in the development of a management plan for the park.

\section{Materials and Methods}

An expedition to the Manuel Luiz Marine State Park took place June 25 - 28, 1998. All specimens were collected by SCUBA diving, with the aid of chisels and hammers, in a total of 8 dives. Depths ranged from 0 to $30 \mathrm{~m}$. Specimens were numbered and photographed and pertinent data was recorded in a log book (date and depth of collection, color, and substrate). Specimens were later transported to the Laboratório de Ambientes Recifais of the Universidade Federal Rural de Pernambuco (LAR/UFRPE), where they were cleared in a solution of $20 \%$ sodium hypochlorite, dried and then analyzed and identified. Morphometric characters analyzed included growth form, corallite diameter, number of columella centers per $\mathrm{cm}^{2}$, length of corallum meander, distance between columella centers, and total number of septa. Information on the growth form, surface texture, dactylopores, gastropores, and ampullae were recorded for the calcified hydroids using vernier calipers and under a stereoscopic microscope equipped with an ocular micrometer. Ten corallites per colony were analyzed for 12 species of scleractinian corals; of the 3 species of Millepora, 25 dactylopores and gastropores were measured on each colony. Stylaster roseus was not collected, only observed and therefore it was not measured.

\section{Results}

The observed calcified hydroids and corals and their sample quantities were: S. roseus - 1, Millepora alcicornis - 5 (Figures 2 and 3), M. braziliensis - 11 (Figures 2 and 4), Millepora sp. - 12 (Figures 5 and 6), Madracis decactis - 12 (Figures 7), Agaricia agaricites - 3 (Figure 8), A. fragilis - 3 (Figure 9), Siderastrea stellata - 8 (Figures 2 and 10), Porites astreoides - 5 (Figures 2 and 11), P. branneri - 5 (Figures 12), Favia gravida - 1 (Figure 13), F. leptophylla - 7 (Figure 14), Montastraea cavernosa - 3 (Figure 15), Mussismilia hispida - 6 (Figure 16), Meandrina braziliensis - 5 (Figure 17), and Scolymia wellsi - 8 (Figure 18).

\section{Stylaster roseus (Pallas, 1776)}

This species was not collected, but a single specimen was observed at a depth of $30 \mathrm{~m}$ deep.

\section{Millepora alcicornis (Linnaeus, 1758)}

(Figures 2 and 3) - This species was found on shipwrecks, on the ocean floor, and on the base of the pillars that form the Coral Banks. One of the specimens collected covered the base of a gorgonian. Specimens were collected from depths of around $25 \mathrm{~m}$ and their growth form was branching. Most colonies were bleached or dead and covered by algae or other organisms. The gastropores and dactylopores of $M$. alcicornis were larger in diameter than those of the other two species of this family (Table 1). 


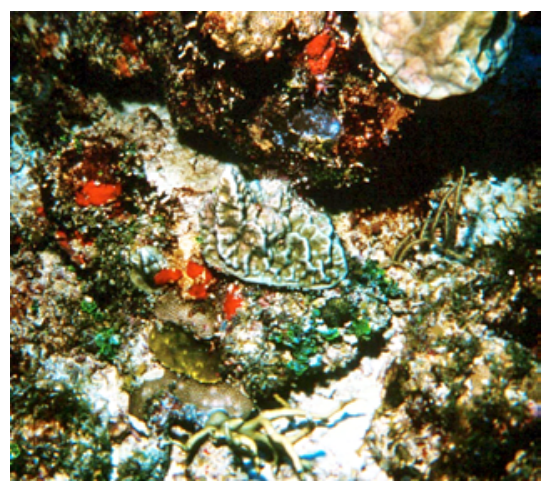

Figure 2. Submarine photograph representing the diversity of some corals (Siderastrea stellata and Porites astreoides) and calcified hydroids (honey-combed Millepora braziliensis above and in the center and branching Millepora alcicornis at the bottom in the left side) of the Manuel Luiz Marine State Park (state of Maranhão, Northeast Brazil). Photo by Luiz Rocha.

Figura 2. Fotografia submarina representando a diversidade de alguns corais (Siderastrea stellata e Porites astreoides) e hidróides calcários (Millepora braziliensis com forma "honey-combed", em cima e no centro, e Millepora alcicornis ramificado abaixo no lado esquerdo) do Parque Estadual Marinho do Manuel Luiz (Estado do Maranhão, Nordeste do Brasil). Foto de Luiz Rocha.

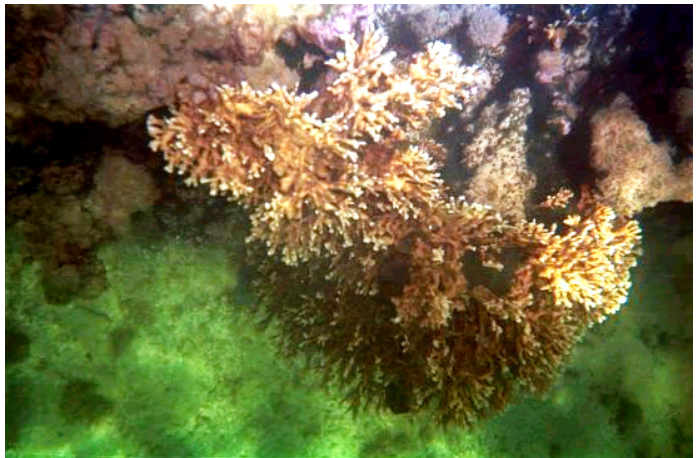

Figure 3. Millepora alcicornis. Photo by Fábio Lang da Silveira.

Figura 3. Millepora alcicornis. Foto de Fábio Lang da Silveira.

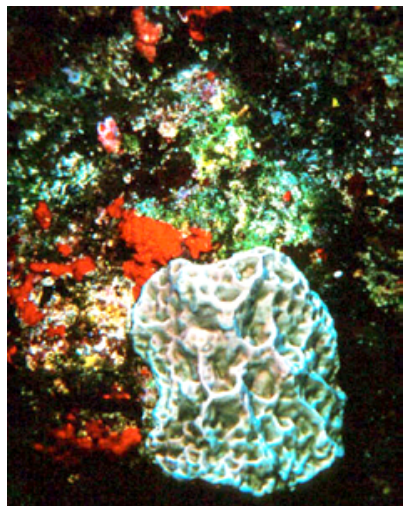

Figure 4. Millepora braziliensis at the Manuel Luiz Marine State Park (state of Maranhão, Northeast Brazil). Photo by Luiz Rocha.

Figura 4. Millepora braziliensis no Parque Estadual Marinho do Manuel Luiz (Estado do Maranhão, Nordeste do Brasil). Foto de Luiz Rocha.

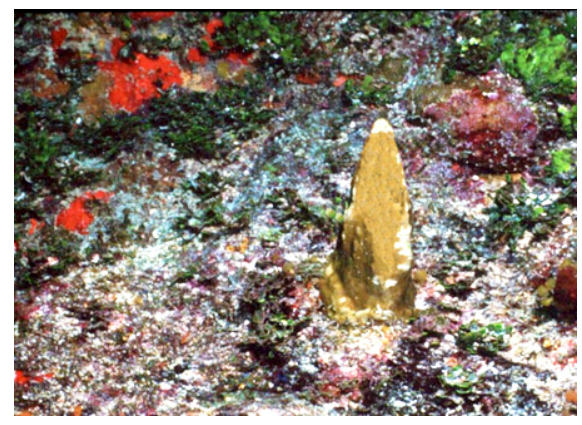

Figure 5. Millepora sp. at the Manuel Luiz Marine State Park (state of Maranhão, Northeast Brazil). Photo by Luiz Rocha.

Figura 5. Millepora sp. no Parque Estadual Marinho do Manuel Luiz (Estado do Maranhão, Nordeste do Brasil). Foto de Luiz Rocha.

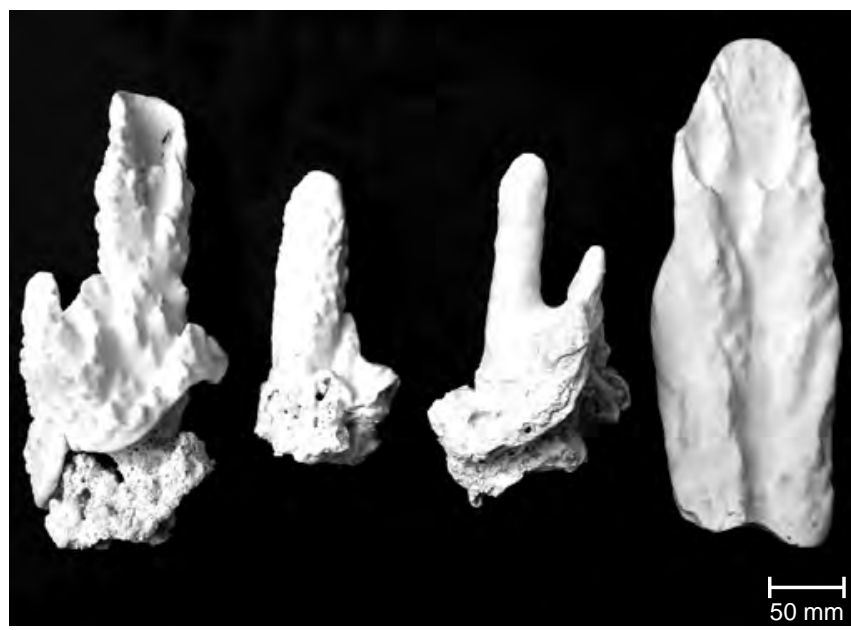

Figure 6. Specimens of Millepora sp. collected at the Manuel Luiz Marine State Park (state of Maranhão, Northeast Brazil). (Scale $=50 \mathrm{~mm}$ ) Photo by Fernando Azevedo.

Figura 6. Espécimes de Millepora sp. coletados no Parque Estadual Marinho do Manuel Luiz (Estado do Maranhão, Nordeste do Brasil). (Escala $=50 \mathrm{~mm}$ ) Foto de Fernando Azevedo.

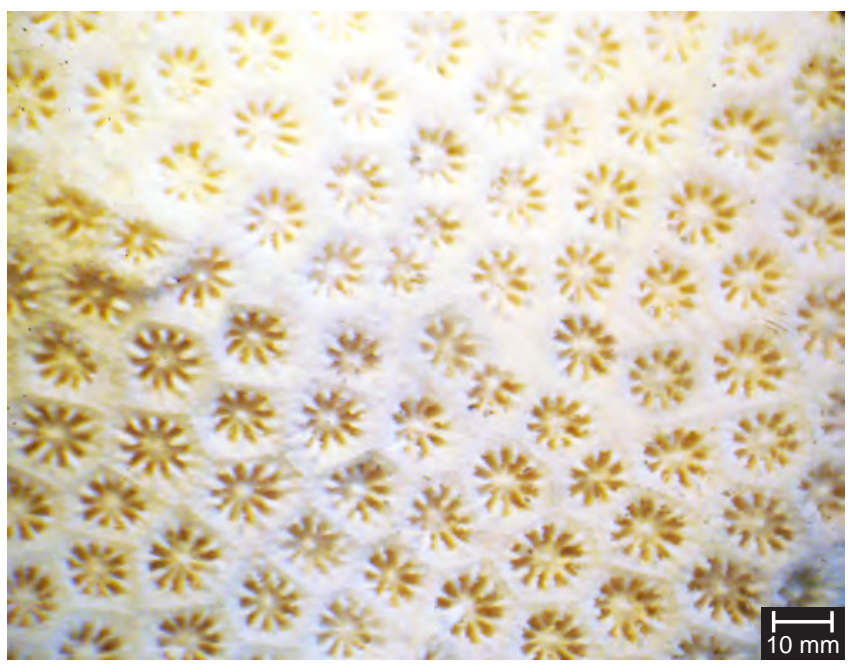

Figure 7. Madracis decactis collected at the Manuel Luiz Marine State Park (state of Maranhão, Northeast Brazil). (Scale $=10 \mathrm{~mm}$ ). Photo by Fernando Azevedo.

Figura 7. Madracis decactis coletado no Parque Estadual Marinho do Manuel Luiz (Estado do Maranhão, Nordeste do Brasil). (Escala $=10 \mathrm{~mm}$ ) Foto de Fernando Azevedo. 


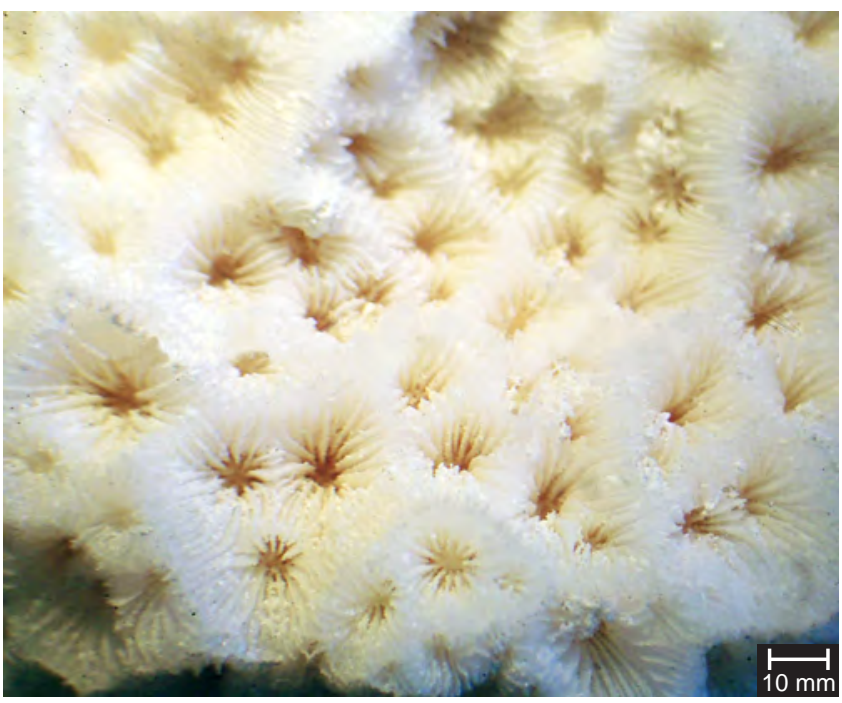

Figure 8. Agaricia agaricites collected at the Manuel Luiz Marine State Park (state of Maranhão, Northeast Brazil). (Scale $=10 \mathrm{~mm}$ ). Photo by Fernando Azevedo.

Figura 8. Agaricia agaricites coletado no Parque Estadual Marinho do Manuel Luiz (Estado do Maranhão, Nordeste do Brasil). (Escala $=10 \mathrm{~mm}$ ) Foto de Fernando Azevedo.

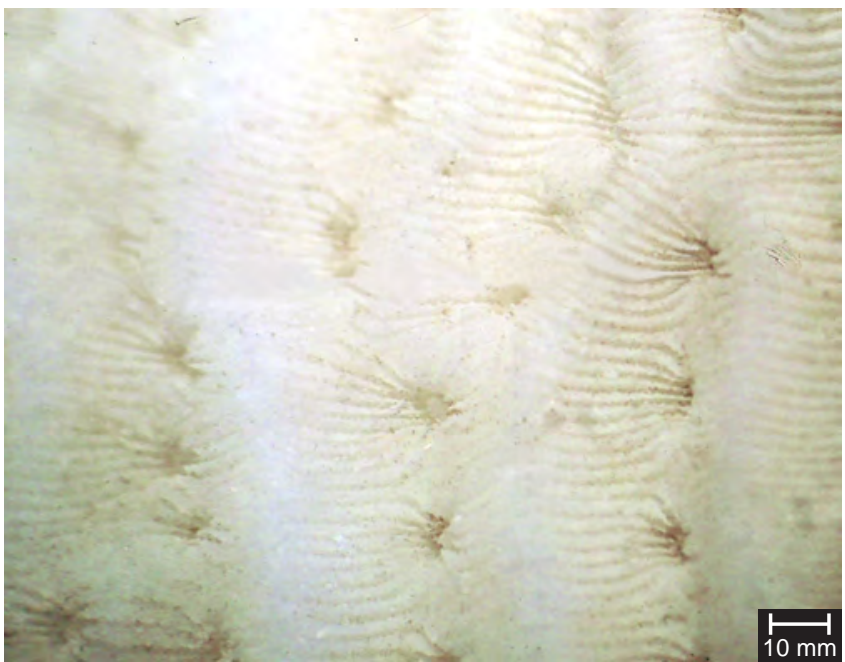

Figure 9. Agaricia fragilis collected at the Manuel Luiz Marine State Park (state of Maranhão, Northeast Brazil). (Scale $=10 \mathrm{~mm}$ ). Photo by Fernando Azevedo.

Figura 9. Agaricia fragilis coletado no Parque Estadual Marinho do Manuel Luiz (Estado do Maranhão, Nordeste do Brasil). (Escala $=10 \mathrm{~mm}$ ) Foto de Fernando Azevedo.

\section{Millepora braziliensis (Verrill, 1868)}

(Figures 2 and 4) - This species, endemic to Brazil, formed large colonies, especially at greater depths (around $30 \mathrm{~m}$ ). Most samples observed were bleached, and some were dead and covered by algae and other organisms. The growth form was columnar or wall-like, with rugged surfaces; the colony shape was honeycombed. The substrate this calcified hydroids grew on was coralline algae. Compared to the other two Milleporidae found (M. alcicornis and Millepora sp.), the dactylopores and gastropores of this species were relatively small, constant in number, and with the greatest number of dactylopores closely surrounding each gastropore (Table 1). We will call the latter dactylopores of the first cycle.

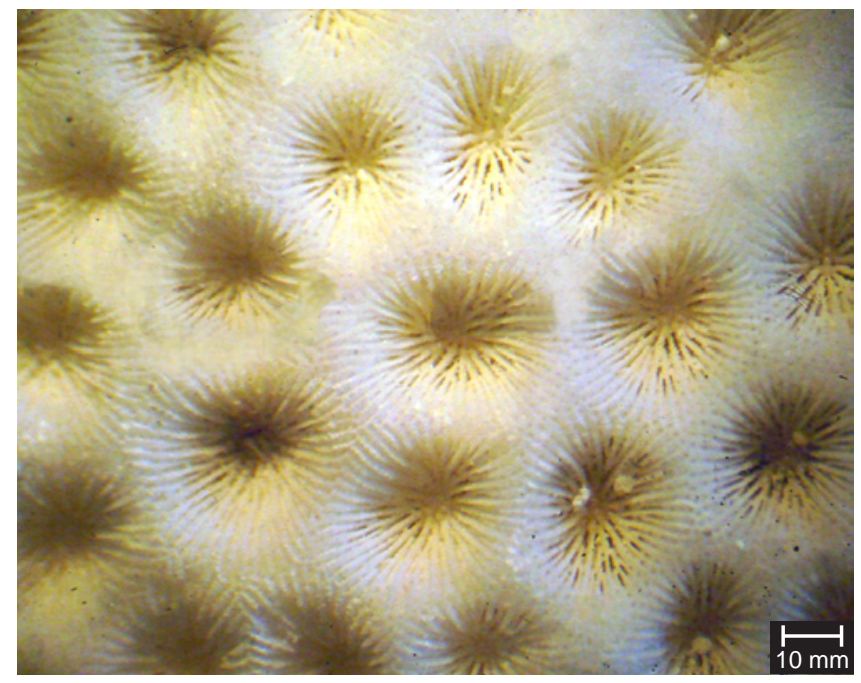

Figure 10. Siderastrea stellata collected at the Manuel Luiz Marine State Park (state of Maranhão, Northeast Brazil). (Scale $=10 \mathrm{~mm}$ ). Photo by Fernando Azevedo.

Figura 10. Siderastrea stellata coletado no Parque Estadual Marinho do Manuel Luiz (Estado do Maranhão, Nordeste do Brasil). (Escala $=10 \mathrm{~mm}$ ) Foto de Fernando Azevedo.

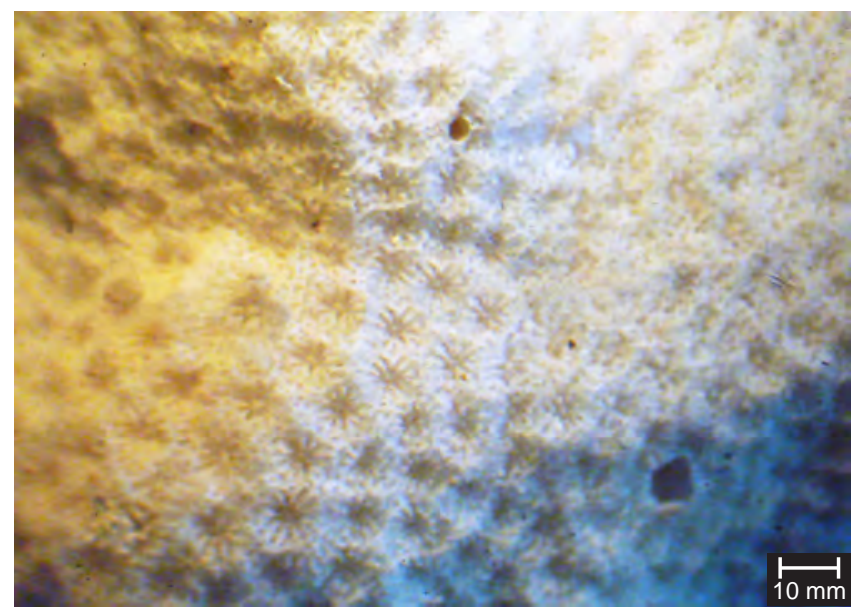

Figure 11. Porites astreoides collected at the Manuel Luiz Marine State Park (state of Maranhão, Northeast Brazil). (Scale $=10 \mathrm{~mm}$ ). Photo by Fernando Azevedo.

Figura 11. Porites astreoides coletado no Parque Estadual Marinho do Manuel Luiz (Estado do Maranhão, Nordeste do Brasil). (Escala $=10 \mathrm{~mm}$ ) Foto de Fernando Azevedo.

\section{Millepora sp.}

(Figures 5 and 6) - Amaral (1997) and Amaral et al. (2002a) cited a previously undescribed species which is endemic to the Manuel Luiz Marine State Park. Colonies observed were up to $1 \mathrm{~m}$ tall, had a columnar shape, and were fixed to the substrate (coralline algae) at deeper localities $(30 \mathrm{~m}$ ). Like the other specimens of this genus, these were bleached. Of the Millepora studied, this species had the smallest dactylopore and gastropore diameters (which in certain parts of the colony were almost imperceptible), as well as the smallest number of dactylopores in the first cycle (Table 1).

\section{Madracis decactis (Lyman, 1859)}

(Figure 7) - This species was abundant on the pillars of the Coral Banks, except near the surface. The growth form varied from 


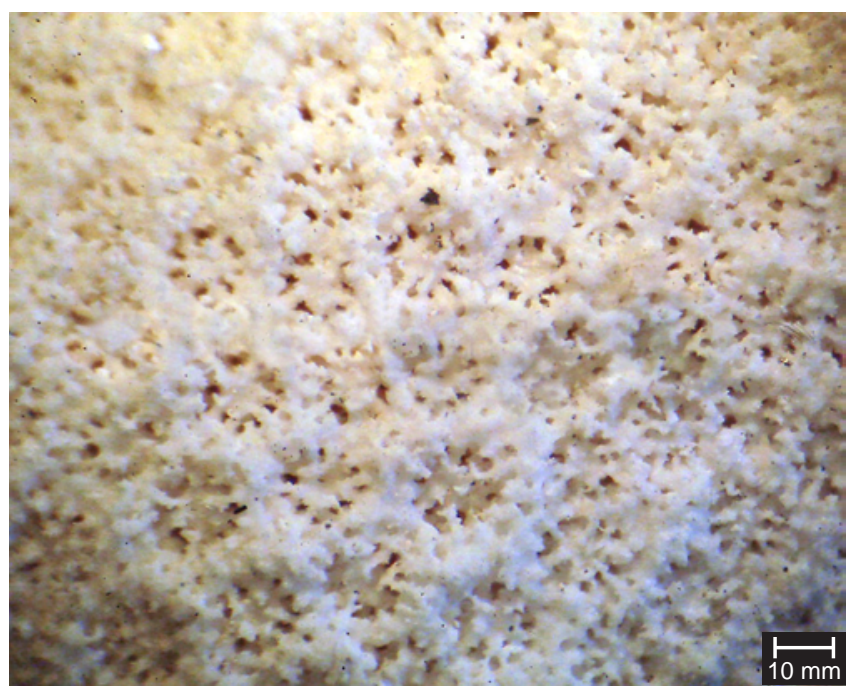

Figure 12. Porites branneri collected at the Manuel Luiz Marine State Park (state of Maranhão, Northeast Brazil). (Scale $=10 \mathrm{~mm}$ ). Photo by Fernando Azevedo.

Figura 12. Porites branneri coletado no Parque Estadual Marinho do Manuel Luiz (Estado do Maranhão, Nordeste do Brasil). (Escala $=10 \mathrm{~mm}$ ) Foto de Fernando Azevedo.

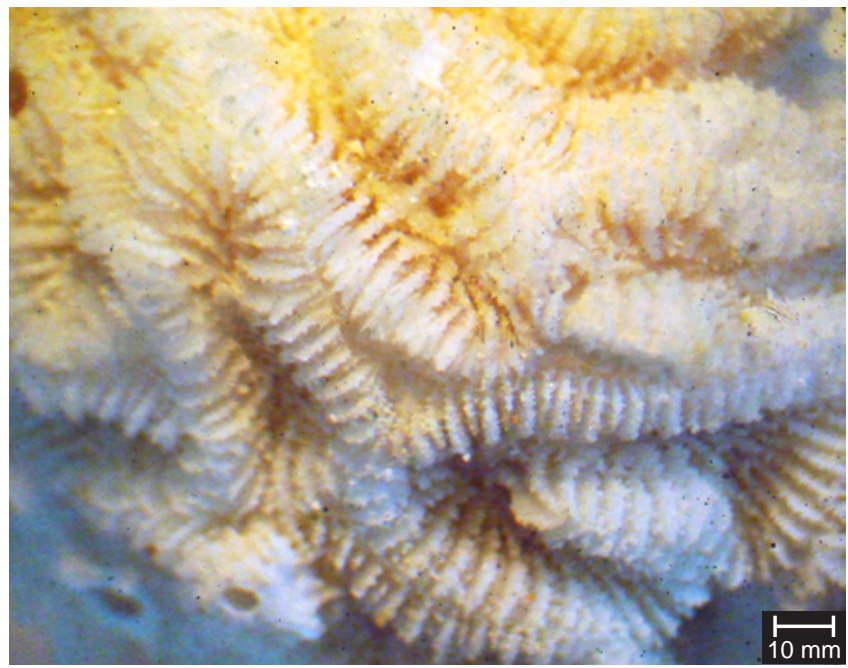

Figure 13. Favia gravida collected at the Manuel Luiz Marine State Park (state of Maranhão, Northeast Brazil). (Scale $=10 \mathrm{~mm}$ ) Photo by Fernando Azevedo.

Figura 13. Favia gravida coletado no Parque Estadual Marinho do Manuel Luiz (Estado do Maranhão, Nordeste do Brasil). (Escala $=10 \mathrm{~mm}$ ) Foto de Fernando Azevedo.

location to location, ranging from columnar to spherical, with small, branched lobes. Coralline algae served as substrate. The color varied from green to brown, and some specimens were bleached. The total number of septa per corallite was quite regular (Table 2); corallites were circular and homogeneous with pentagonal outlines, and were distributed symmetrically over the colony.

\section{Agaricia agaricites (Linnaeus, 1758)}

(Figure 8) - This species was found in shaded areas. The color varied from yellow to light green. Some specimens had green

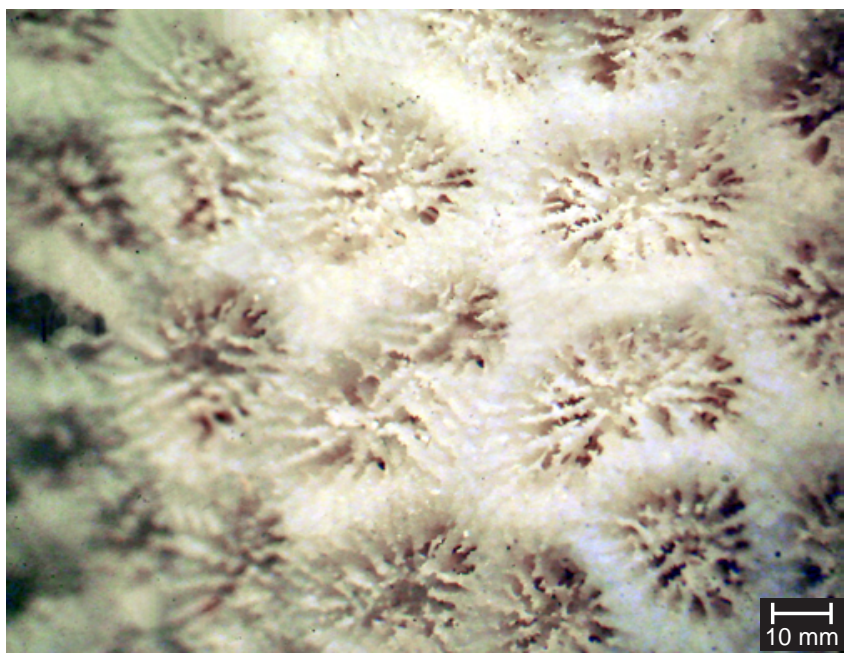

Figure 14. Favia leptophylla collected at the Manuel Luiz Marine State Park (state of Maranhão, Northeast Brazil). (Scale $=10 \mathrm{~mm}$ ). Photo by Fernando Azevedo.

Figura 14. Favia leptophylla coletado no Parque Estadual Marinho do Manuel Luiz (Estado do Maranhão, Nordeste do Brasil). (Escala $=10 \mathrm{~mm}$ ) Foto de Fernando Azevedo.

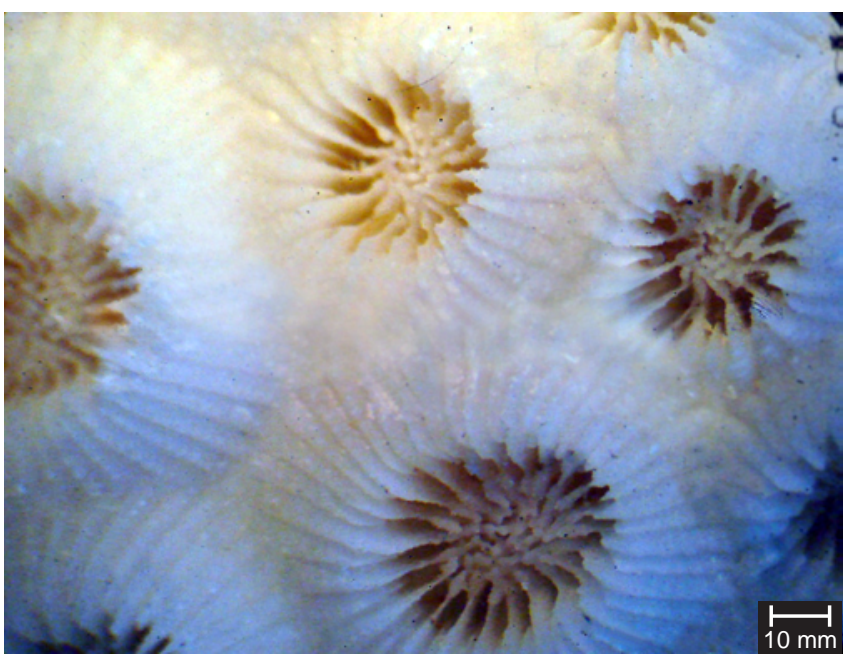

Figure 15. Montastraea cavernosa collected at the Manuel Luiz Marine State Park (state of Maranhão, Northeast Brazil). (Scale $=10 \mathrm{~mm}$ ). Photo by Fernando Azevedo.

Figura 15. Montastraea cavernosa coletado no Parque Estadual Marinho do Manuel Luiz (Estado do Maranhão, Nordeste do Brasil). (Escala $=10 \mathrm{~mm}$ ) Foto de Fernando Azevedo.

phosphorescent spots and several were bleached. The substrate was predominantly coralline algae. Colonies were flattened to spherical. The total number of septa was high (Table 2) compared to A. fragilis, and corallites were irregular in shape. Colony height and width were considerably smaller than $A$. fragilis.

\section{Agaricia fragilis (Dana, 1846)}

(Figure 9) - This species was found in deeper regions. Its color was similar to A. agaricites, but colonies were larger. Some bleaching was observed. Fragments studied (Table 2) had circular corallites, which were larger and slightly closer together than those of $P$. astreoides. 


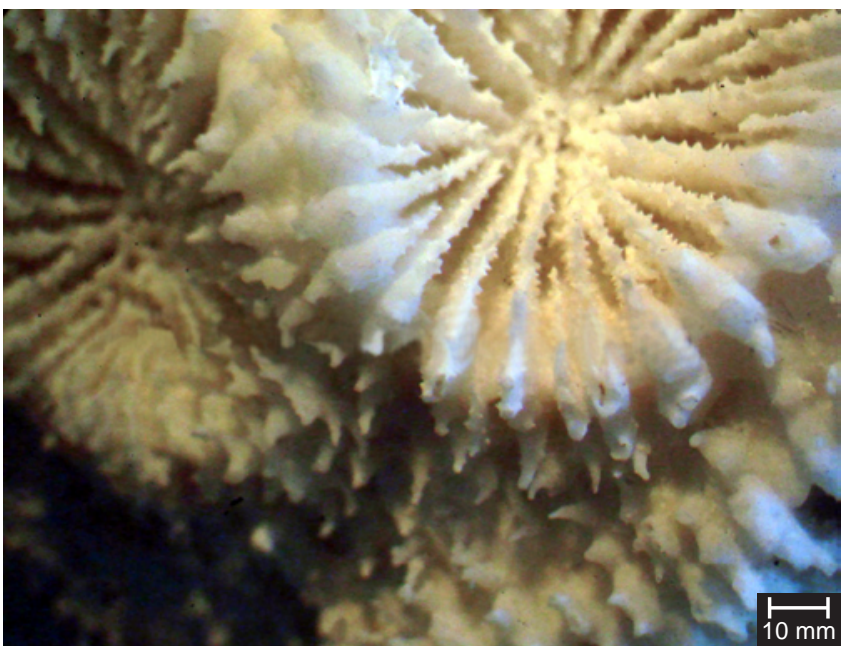

Figure 16. Mussismilia hispida collected at the Manuel Luiz Marine State Park (state of Maranhão, Northeast Brazil). (Scale $=10 \mathrm{~mm}$ ). Photo by Fernando Azevedo.

Figura 16. Mussismilia hispida coletado no Parque Estadual Marinho do Manuel Luiz (Estado do Maranhão, Nordeste do Brasil). (Escala $=10 \mathrm{~mm}$ ) Foto de Fernando Azevedo.

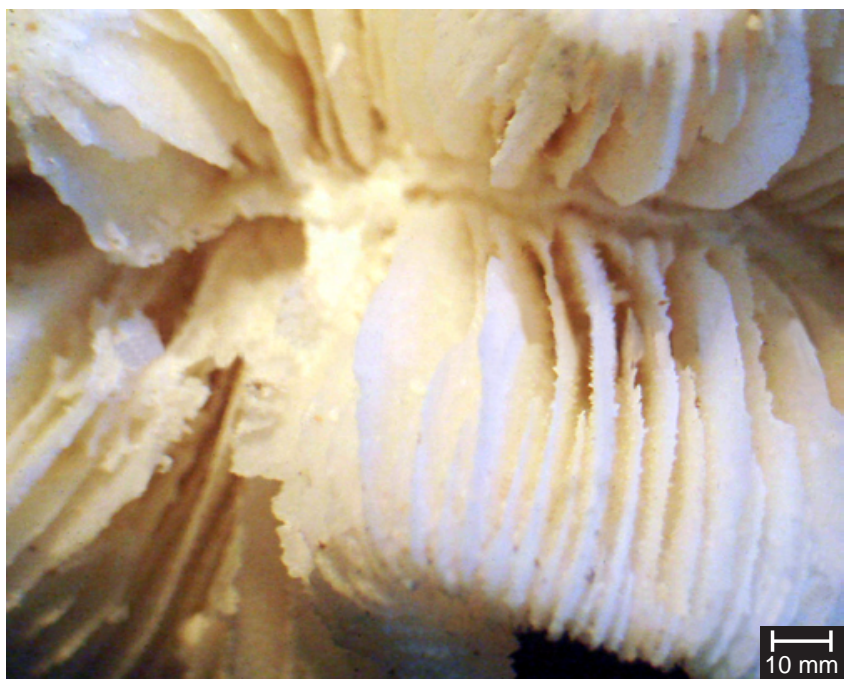

Figure 17. Meandrina braziliensis collected at the Manuel Luiz Marine State Park (state of Maranhão, Northeast Brazil). (Scale $=10 \mathrm{~mm}$ ). Photo by Fernando Azevedo.

Figura 17. Meandrina braziliensis coletado no Parque Estadual Marinho do Manuel Luiz (Estado do Maranhão, Nordeste do Brasil). (Escala = $10 \mathrm{~mm}$ ) Foto de Fernando Azevedo.

\section{Siderastrea stellata Verrill, 1868}

(Figure 10) - This species, endemic to Brazil was found in all depths, especially on shipwrecks and on coralline algae. The color varied from brick red to light pink; several white specimens were observed due to bleaching. Species had a flattened to hemispheric shape; no incrusting specimens were found. The characters studied did not vary greatly, especially corallite diameter and distances between columella centers. The specimens analyzed had four incomplete septa cycles and considerable distances between columella centers when compared to other corals of the park (Table 2).

\section{Porites astreoides Lamarck, 1816}

(Figure 11) - This species was found at depths of about $20 \mathrm{~m}$. Most were large, conically shaped, and yellow in color. Bleached

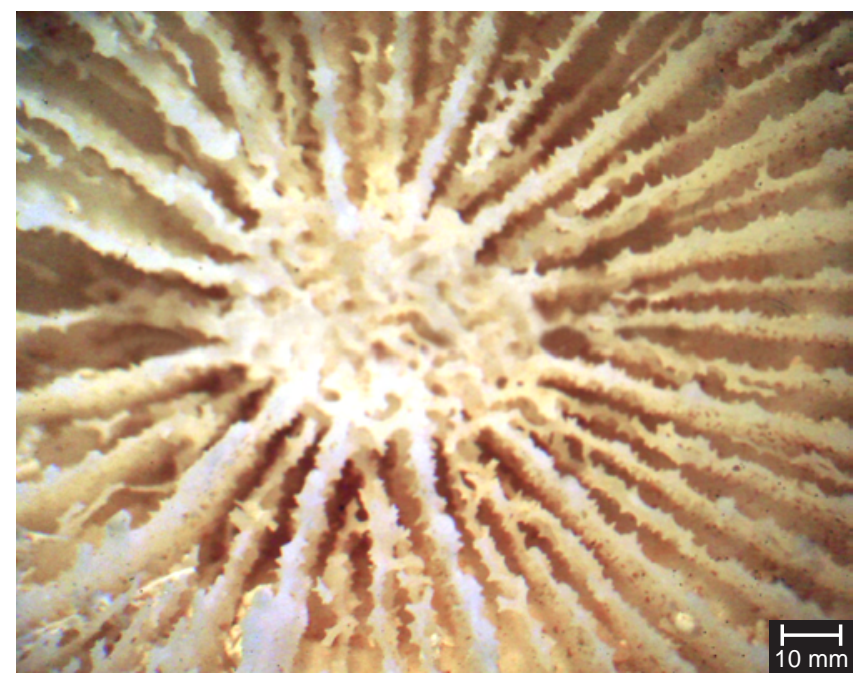

Figure 18. Scolymia wellsi collected at the Manuel Luiz Marine State Park (state of Maranhão, Northeast Brazil). (Scale $=10 \mathrm{~mm}$ ). Photo by Fernando Azevedo.

Figura 18. Scolymia wellsi coletado no Parque Estadual Marinho do Manuel Luiz (Estado do Maranhão, Nordeste do Brasil). (Escala $=10 \mathrm{~mm}$ ) Foto de Fernando Azevedo.

specimens were also observed. The samples analyzed had a relatively stable number of septa and small, round corallites that were densely grouped at a regular distance. Comparatively, this species' characters were closest to those of $P$. branneri, with same differences as the corallite diameter, which was smaller (Table 2).

\section{Porites branneri Rathbun, 1888}

(Figure 12) - This species was always found in the same areas of $P$. astreoides, yet with smaller colonies that were darker in color (several shades of brown) and incrusting forms. Some colonies were partially or totally bleached. The samples analyzed had circular corallites, larger and slightly closer than those of $P$. astreoides (Table 2).

\section{Favia gravida Verrill, 1868}

(Figure 13) - Only one specimen of this coral was found, in a shallow area on a pillar. It was yellow, had an irregular hemispheric shape, and was not bleached. Coralline algae served as substrate. The total number of septa (Table 2) was higher than in F. leptophylla. The corallite diameter and distances between columella were also larger.

\section{Favia leptophylla Verrill, 1868}

(Figure 14) - This species was more abundant than $F$. gravida and occurred in depths around $25 \mathrm{~m}$. Color varied from light yellow to green, with some bleached specimens. Colony size was $15 \mathrm{~cm}$ in average and the shape varied from hemispheric to flattened. Coralline algae served as substrate. The total number of septa (Table 2) was smaller and had less variation than $F$. gravida. Distance between columella centers was almost constant, with only slight variation.

\section{Montastraea cavernosa (Linnaeus, 1767)}

(Figure 15) - This species was observed in depths between 20 and $30 \mathrm{~m}$, forming colonies of up to $2 \mathrm{~m}$ in diameter. Smaller specimens were observed on shipwrecks. The color was brown, and some bleaching was observed. Coralline algae served as the substrate. Among the Faviidae, this species was the largest and had the greatest distances between columella centers. Four incomplete septa cycles were observed (Table 2). 


\section{Mussismilia hispida (Verrill, 1868)}

(Figure 16) - This species was found on pillar bases and on shipwrecks. Specimens were in average $50 \mathrm{~cm}$ in diameter. The colony from which a fragment was collected was bleached and was found at $25 \mathrm{~m}$. Data collected from this fragment served mainly to identify the species, as it was quite small (Table 2). Four incomplete septa cycles were observed. Corallites were relatively large and had rounded shapes.

\section{Meandrina braziliensis (Milne Edwards and Haime, 1849)}

(Figure 17) - This species was found on sandy bottoms at an average depth of $30 \mathrm{~m}$. Colonies in different developmental stages were observed. The color varied from light yellow to partially white due to bleaching. Colonies studied were young and therefore character data varied (Table 3). Since corallite limits could not be visualized clearly, they were not analyzed.

\section{Scolymia wellsi (Laborel, 1967)}

(Figure 18) - This solitary species (Table 4) was found in depths of around $30 \mathrm{~m}$, in shaded areas. Shape was flattened and color varied from brown to green, and sometimes white due to bleaching. Substrate was coralline algae.

Among other cnidarian groups, 1 species of hydroid Tyroscyphus sp. (Figure 19), 2 species of sea anemones: Condylactis gigantea (Figure 20) and Bunodosoma cangicum, 1 species of zoanthid (Palythoa sp.), and 1 species of octocoral (Phyllogorgia dilatata) (Figure 21) were also recorded.

\section{Discussion and Conclusions}

According to Laborel (1969, 1970), a single coral species (Meandrina braziliensis) and no calcified hydroids occurred on the coast of Maranhão. However, his collections were restricted to the coastal waters, which are turbid all year due to sediment run-off from the rivers, especially the Amazon River. Coura (1994) was the first to study the fauna of the Marine State Park of the Manuel Luiz Marine State Park, listing 4 coral genera and 1 calcified hydroid genus. In the present study, there were found several other coral genera: Porites, Favia, Montastraea, and Scolymia, as well as the calcified hydroids Stylaster roseus and Millepora sp. In addition, the bathymetric and geographic distribution of the 16 species found was enlarged.

Comparatively, the diversity of the Manuel Luiz Park surpasses that of two other important, yet geographically distinct areas. In a study carried out at the Rocas Atoll (Rio Grande do Norte State), Echeverría et al. (1997) found the corals Madracis decactis, Agaricia agaricites, Siderastrea stellata, Porites astreoides, P. branneri, Favia gravida, Montastraea cavernosa, and Mussismilia hispida and the calcified hydroids Millepora alcicornis and M. braziliensis; yet the corals Agaricia fragilis, Favia leptophylla, Scolymia wellsi, and Meandrina braziliensis and the calcified hydroids Millepora sp. and Stylaster roseus, found in this study, were not recorded for the

Table 1. Mean (mm) and standard error of the characters studied for calcified hydroids Millepora braziliensis $(\mathrm{n}=2)$, Millepora alcicornis $(\mathrm{n}=4)$, and Millepora sp. $(\mathrm{n}=5)$ of the Manuel Luiz Marine State Park.

Tabela 1. Medidas $(\mathrm{mm})$ e erro padrão dos caracteres estudados para os hidróides calcários Millepora braziliensis $(\mathrm{n}=2)$, Millepora alcicornis $(\mathrm{n}=4)$, e Millepora sp. $(\mathrm{n}=5)$ do Parque Estadual Marinho do Manuel Luiz.

\begin{tabular}{lccc}
\hline \multicolumn{1}{c}{ Characters } & M. braziliensis & M. alcicornis & M. sp. \\
\hline Gastropore diameter & $0.200 \pm 0.009$ & $0.260 \pm 0.009$ & $0.170 \pm 0.007$ \\
Dactilopore diameter & $0.090 \pm 0.004$ & $0.150 \pm 0.004$ & $0.080 \pm 0.003$ \\
Number of dactilopores of the first cycle & $5.200 \pm 0.287$ & $4.780 \pm 0.136$ & $4.480 \pm 0.237$ \\
Number of gastropores per cm ${ }^{2}$ & $18.000 \pm 1.126$ & $16.580 \pm 1.574$ & $18.800 \pm 1.826$ \\
Colony height & $185.000 \pm 5.000$ & $192.000 \pm 33.658$ & $145.380 \pm 15.424$ \\
Colony width & $120.000 \pm 66.000$ & $106.000 \pm 14.916$ & $69.040 \pm 7.114$ \\
\hline
\end{tabular}

Table 2. Mean $(\mathrm{mm})$ and standard error of the characters studied for the corals Madracis decactis $(\mathrm{n}=5)$, Agaricia agaricites $(\mathrm{n}=3)$, A. fragilis $(\mathrm{n}=5)$, Siderastrea stellata $(\mathrm{n}=5)$, Porites astreoides $(\mathrm{n}=5)$, P. branneri $(\mathrm{n}=5)$, Favia gravida $(\mathrm{n}=1)$, F. leptophylla $(\mathrm{n}=5)$, Montastraea cavernosa $(\mathrm{n}=5)$, Mussismilia hispida $(\mathrm{n}=1)$, of the Manuel Luiz Marine State Park.

Tabela 2. Medidas (mm) e erro padrão dos caracteres estudados para os corais Madracis decactis $(\mathrm{n}=5)$, Agaricia agaricites $(\mathrm{n}=3)$, A. fragilis $(\mathrm{n}=5)$, Siderastrea stellata $(\mathrm{n}=5)$, Porites astreoides $(\mathrm{n}=5)$, P. branneri $(\mathrm{n}=5)$, Favia gravida $(\mathrm{n}=1)$, F. leptophylla $(\mathrm{n}=5)$, Montastraea cavernosa $(\mathrm{n}=5)$, Mussismilia hispida $(\mathrm{n}=1)$, do Parque Estadual Marinho do Manuel Luiz.

\begin{tabular}{lcccccc}
\hline \multicolumn{1}{c}{ Characters } & $\begin{array}{c}\text { Total number } \\
\text { of septa }\end{array}$ & $\begin{array}{c}\text { Corallite } \\
\text { diameter }\end{array}$ & $\begin{array}{l}\text { Distance between } \\
\text { columella centers }\end{array}$ & $\begin{array}{c}\text { Number of } \\
\text { columella } \\
\text { centers / cm } \mathbf{~}^{2}\end{array}$ & Colony height & Colony width \\
\hline Madracis decactis & $10.360 \pm 0.281$ & $2.120 \pm 0.036$ & $1.870 \pm 0.038$ & $24.530 \pm 1.352$ & $50.600 \pm 13.110$ & $75.200 \pm 10.361$ \\
Agaricia agaricites & $28.230 \pm 1.416$ & $2.230 \pm 0.104$ & $1.920 \pm 0.092$ & $22.670 \pm 1.364$ & $14.000 \pm 2.650$ & $48.330 \pm 10.039$ \\
Agaricia fragilis & $19.400 \pm 0.807$ & $2.860 \pm 0.166$ & $1.780 \pm 0.081$ & $14.110 \pm 0.964$ & $20.670 \pm 6.692$ & $100.330 \pm 5.897$ \\
Siderastrea stellata & $43.220 \pm 0.580$ & $3.440 \pm 0.059$ & $3.450 \pm 0.061$ & $8.930 \pm 0.408$ & $25.400 \pm 4.884$ & $79.600 \pm 11.210$ \\
Porites astreoides & $12.320 \pm 0.217$ & $1.790 \pm 0.329$ & $1.510 \pm 0.034$ & $38.540 \pm 2.928$ & - & - \\
Porites branneri & $11.780 \pm 0.174$ & $3.470 \pm 2.103$ & $1.300 \pm 0.029$ & $38.600 \pm 1.600$ & - & - \\
Favia gravida & $46.100 \pm 2.669$ & $6.470 \pm 0.319$ & $4.520 \pm 0.127$ & $4.330 \pm 0.333$ & - & - \\
Favia leptophylla & $31.560 \pm 0.721$ & $4.190 \pm 0.136$ & $3.940 \pm 0.069$ & $5.130 \pm 0.256$ & $16.800 \pm 2.035$ & $46.800 \pm 5.678$ \\
Montastraea cavernosa & $38.430 \pm 0.796$ & $5.557 \pm 0.154$ & $7.577 \pm 0.236$ & $2.444 \pm 0.176$ & $24.500 \pm 5.500$ & $112.500 \pm 6.500$ \\
Mussismilia hispida & $35.750 \pm 2.914$ & $14.760 \pm 0.604$ & $16.420 \pm 1.226$ & $3.670 \pm 0.333$ & - & - \\
\hline
\end{tabular}


Table 3. Mean ( $\mathrm{mm}$ ) and standard error of the characters studied for the coral Meandrina braziliensis $(\mathrm{n}=5)$ of the Manuel Luiz Marine State Park.

Tabela 3. Medidas (mm) e erro padrão dos caracteres estudados para o coral Meandrina braziliensis $(\mathrm{n}=5)$ do Parque Estadual Marinho do Manuel Luiz.

\begin{tabular}{lc}
\hline \multicolumn{1}{c}{ Characters } & Meandrina braziliensis \\
\hline Colony height & $28.980 \pm 4.103$ \\
Colony width & $28.800 \pm 3.741$ \\
Colony length & $46.900 \pm 5.001$ \\
Largest colony diameter & $20.820 \pm 2.412$ \\
\hline
\end{tabular}

Table 4. Mean (mm) and standard error of the characters studied for the coral Scolymia wellsi $(\mathrm{n}=5)$ of the Manuel Luiz Marine State Park.

Tabela 4. Medidas (mm) e erro padrão dos caracteres estudados para o coral Scolymia wellsi $(\mathrm{n}=5)$ do Parque Estadual Marinho do Manuel Luiz.

\begin{tabular}{lr}
\hline \multicolumn{1}{c}{ Characters } & Scolymia wellsi \\
\hline Total number of septa & $78.600 \pm 3.655$ \\
Number of septa of the first cycle & $12.000 \pm 0.000$ \\
Number of septa of the last cycle & $8.200 \pm 1.114$ \\
Septa width & $0.824 \pm 0.116$ \\
Width of the external columella & $6.380 \pm 0.326$ \\
Corallite diameter & $36.740 \pm 1.285$ \\
Corallite height & $27.740 \pm 3.026$ \\
\hline
\end{tabular}

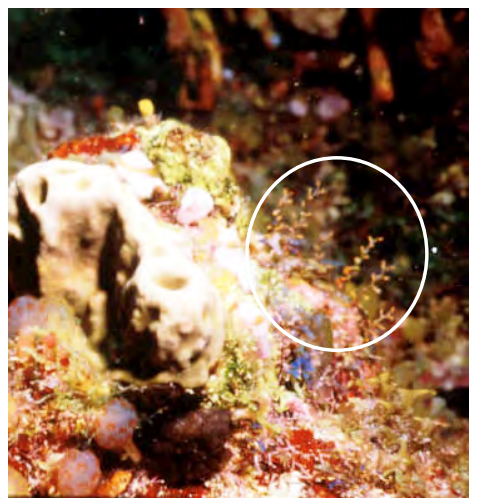

Figure 19. Tyroscyphus sp. at the Manuel Luiz Marine State Park (state of Maranhão, Northeast Brazil). Photo by Luiz Rocha.

Figura 19. Tyroscyphus sp. no Parque Estadual Marinho do Manuel Luiz (Estado do Maranhão, Nordeste do Brasil). Foto de Luiz Rocha.

atoll. Another example is the Fernando de Noronha Archipelago (Pernambuco State) which is a volcanic archipelago, where Pires et al. (1992) recorded 9 coral species (genera Madracis, Agaricia, Siderastrea, Porites, Favia, Montastraea, and Mussismilia) and 2 calcified hydroids species (genera Stylaster and Millepora), once again a number lower than that found in this study.

Thus, the Manuel Luiz' diversity, in Brazil, is comparable only to that of the Abrolhos Islands (Bahia State), which is a volcanic archipelago. According to Hetzel and Castro (1994), 15 zooxanthellate corals, 2 azooxanthellate corals, and 4 calcified hydroids species occur in that region. In Abrolhos, this species richness is due to the region's warm, shallow, relatively clear waters with little plankton

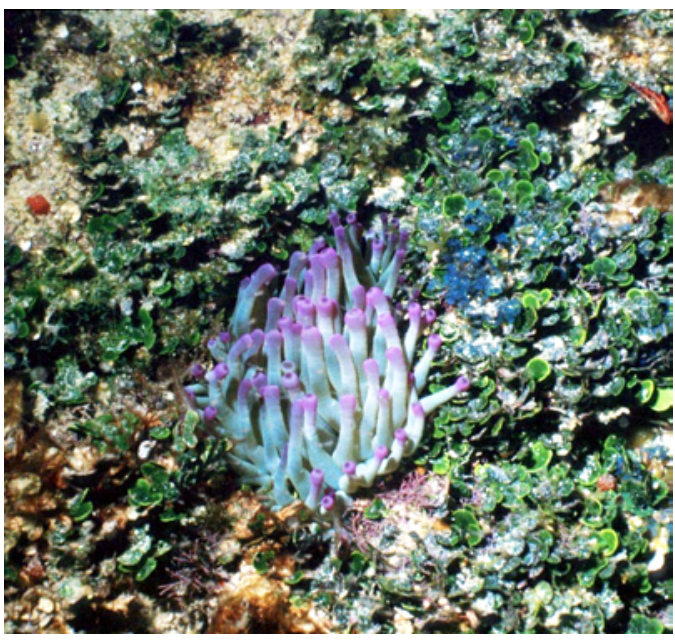

Figure 20. Condylactis gigantea at the Manuel Luiz Marine State Park (state of Maranhão, Northeast Brazil). Photo by Luiz Rocha.

Figura 20. Condylactis gigantea no Parque Estadual Marinho do Manuel Luiz (Estado do Maranhão, Nordeste do Brasil). Foto de Luiz Rocha.

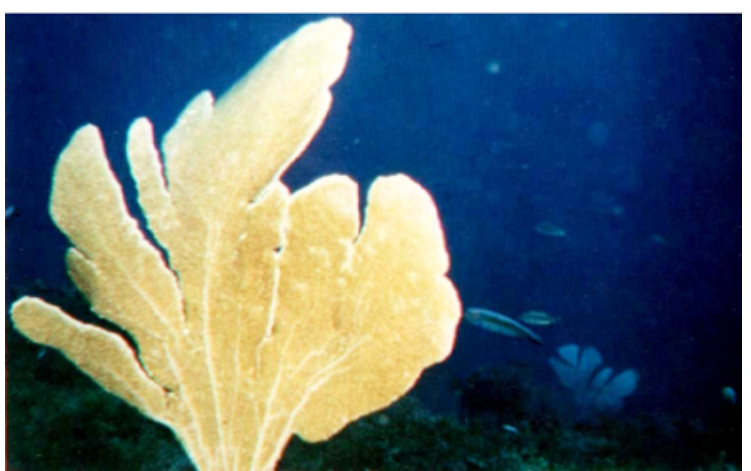

Figure 21. Phyllogorgia sp. at the Manuel Luiz Marine State Park (state of Maranhão, Northeast Brazil). Photo by Luiz Rocha.

Figura 21. Phyllogorgia sp. no Parque Estadual Marinho do Manuel Luiz (Estado do Maranhão, Nordeste do Brasil). Foto de Luiz Rocha.

(Hetzel and Castro 1994), uncommon in the Manuel Luiz Marine State Park region.

The distance from the coast can explain the coral and calcified hydroids diversity of the Coral Banks, augmented by strong ocean currents that limit the arrival of sediment-rich waters from the Amazon River Basin. Therefore, it becomes an ideal area for the development of this type of fauna. However, the strong currents and remote nature also make research in the area difficult, which explains the lack of previous studies of cnidarian fauna.

\section{Acknowledgments}

We are most grateful to Dr. Stephen Cairns (Smithsonian Institution) for his important comments on this text and to Dr. Fábio Lang da Silveira (Universidade de São Paulo) and Dr. Nancy Knowlton (University of California) for their suggestions on the earlier version of the manuscript. Many thanks to the CNPq for the first author's research fellowship. The authors would like to thank the anonymous reviewers for helping improve this paper. 


\section{References}

AMARAL, F.D. 1997. Milleporidae (Cnidaria, Hydrozoa) do litoral brasileiro. 204 f. Tese de Doutorado. Universidade de São Paulo. São Paulo.

AMARAL, F.D., BROADHURST, M.K., CAIRNS, S.D. \& SCHLENZ, E. 2002a. Skeletal morphometry of Millepora occurring in Brazil, including a previously undescribed species. Proc. Biol. Soc. Wash.115(3):681-695.

AMARAL, F.D., HUDSON, M.M. \& COURA, M.F. 1998. Levantamento preliminar dos corais e hidrocorais do Parque Estadual Marinho do Coral Banks do Manuel Luiz (MA). In: Simpósio de Biologia Marinha, 13, 1998. Resumos... São Sebastião: Cebimar-USP, p. 13.

AMARAL, F.D., HUDSON, M.M., SILVEIRA, F.L., MIGOTTO, A.E.,PINTO, S.M. \& LONGO, L.L. 2002b. Cnidarians of Saint Peter and St. Paul Archipelago, Northeast Brazil. In: Int. Coral Reef Symp., 9, 2000, Bali. Proceedings. Bali: Intern. Coral Reef Soc.1:567-572.

AMARAL, F.D., HUDSON, M. \& STEINER, A. 2006a. Note on the widespread bleaching observed at the Manuel Luiz Marine State Park, Maranhão, Brazil. Arq. Ciênc. Mar 39:138-141.

AMARAL, F.D., SILVEIRA, S.R.M., VASCONCELOS, S.L. \& RAMOS, C.A.C. 2006b. Biodiversidade de cnidários bentônicos. In: VASKE JÚNIOR, T., LESSA, R.P., NÓBREGA, M.F., AMARAL, F.M.D., SILVEIRA, S.R.M. Arquipélago de São Pedro e São Paulo: histórico e recursos naturais. Olinda, Ed. Livrorápido. p. 42-55.

BELÉM, M.J.C., ROHLFS, C., PIRES, D.O., CASTRO, C.B. \& YOUNG, P.S. 1986. S.O.S. Corais. Ciência Hoje 5(26):34-42.

CASTRO, C. B. \& PIRES, D. O. 2001. Brazilian coral reefs: What we already know and what is still missing. Bull. Mar. Sci. 69(2):357-371.

COURA, M.F. 1994. Contribuição ao Plano de Manejo do Parque Estadual Marinho do Parcel do Manuel Luís, MA - Brasil. 55 f. Monografia de Especialização, Universidade Federal do Maranhão, São Luís.

COUTO, E.C.G., SILVEIRA, F.L. \& ROCHA, G.R.A. 2003. Marine biodiversity in Brazil: The current status. Gayana 67(2):327-340.

ECHEVERRÍA, C.A., PIRES, D.O., MEDEIROS, M.S. \& CASTRO, C.B. 1997. Cnidaria of the Atoll das Rocas. In: Int. Coral Reef Symp., 8,
1996, Panama. Proc. Panama: University of Panama and the Smithsonian Tropical Research Institute 1:443-446.

HETZEL, B. \& CASTRO, C.B. 1994. Corais do Sul da Bahia. São Paulo: Nova Fronteira. 189p.

HUDSON, M.M. 2000. Hidrocorais e corais do Parcel do Manuel Luiz (MA) e corais do Arquipélago de São Pedro e São Paulo. 50 f. Monografia de Graduação, Universidade Federal Rural de Pernambuco, Recife.

LABOREL, J. 1969. Les peuplements de madreporaires dês cotes tropicales du Brésil. Ann. Uni. Abidjan, Scr. E. 2(3):1-261.

LABOREL, J. 1970. Madréporaires et hydrocoralliaires récifaux des cotes brésiliennes. Rés. Sci. Camp. Calypso 9(25):171-229.

LEÃO, ZM.A.N. \& KIKUCHI, R.K.P. 2005. A relic coral fauna threatened by global changes and human activities, Eastern Brazil. Mar. Pollut. Bull. 51(5-7):599-611.

LEÃO, Z.M.A.N., KIKUCHI, R.K.P. \& TESTA, V. 2003. Corals and coral reefs of Brazil. Latin American Coral Reefs. Ed. CORTÉS, J., p. 9-52.

MAIDA, M. \& FERREIRA, B.P. 1997. Coral Reefs of Brazil: an overview. In: Int. Coral Reef Symp., 8, 1996, Panama. Proc. Panama: University of Panama and the Smithsonian Tropical Research Institute 1:263-274.

MAŸAL, E. \& BEZERRA, V. 1994/1995. Situação atual dos corais no Atol das Rocas - RN - Brasil: Nota prev. Biol. Bras. 6(1/2):77-80.

MIGOTTO, A.E., SILVEIRA, F.L., SCHLENZ, E. \& FREITAS, J.C. 1999. Filo Cnidaria. In: A.E. MIGOTTO \& C.G. TIAGO, Eds. Biodiversidade do Estado de São Paulo, Brasil, Invertebrados Marinhos. FAPESP, São Paulo, v3. 310p.

PIRES, D.O., CASTRO, C.B., MIGOTTO, A.E. \& MARQUES, A.C. 1992 Cnidários bentônicos de Fernando de Noronha, Brasil. Bolm Mus. Nac. 354:1-21.

PRATES, A.P.L. 2006. Atlas dos Recifes de Coral nas Unidades de Conservação Brasileiras. Brasília: Ministério do Meio Ambiente, $2^{\mathrm{a}}$ ed., 232p.

TRAVASSOS, P., HAZIN, F.H.V., ZAGAGLIA, J.R., ADVÍNCULA, R. \& SCHOBER, J. 1999. Thermohaline structure around seamounts and islets off North-Eastern Brasil. Arch. Fish. Mar. Res. 47(2/3):211-222. 
